\section{Tissue specific variation in bio- chemical compositions of Acorus calamus (L.) leaves and rhizomes}

\author{
Deepak Ganjewala, ${ }^{1}$ Asha Devi S, ${ }^{2}$ \\ Ashwani Kumar Srivastava ${ }^{1}$ \\ ${ }^{1}$ Amity Institute of Biotechnology, Amity \\ University, Noida, India; \\ 2School of Biosciences and Technology, \\ Vellore Institute of Technology \\ University, Vellore, India
}

\begin{abstract}
Sweet Flag (Acorus calamus L.) leaf and rhizome tissues were analyzed for biochemical compositions notably of carbohydrates and lipids. The glycolipid content measured in rhizome tissue was $62.3 \mathrm{mg} \% / \mathrm{FW}$ almost double the glycolipid content $(28.8 \mathrm{mg} \% / \mathrm{FW})$ in leaf tissues, whereas the sterol content in the leaf tissue $(47.9 \mathrm{mg} \% / \mathrm{FW})$ was three times of the sterol content in rhizome tissues (15.5 $\mathrm{mg} \% / \mathrm{FW})$. Carbohydrates content such as total sugar, reducing sugar, sucrose and fructose measured in leaf and rhizome tissues were more or less similar, with slightly higher values of total sugar $(18.2 \mathrm{mg} \% / \mathrm{FW})$ in the leaf tissues. The study thus revealed variation in biochemical compositions in two different tissues leaf and rhizome of A. calamus.
\end{abstract}

\section{Introduction}

Acorus calamus (L.) commonly known as Sweet flag belong to family Araceae is a well known medicinal plant for centuries. Acorus calamus leaves and rhizomes possess many useful biological activities. ${ }^{1-6}$ Several previous studies have reported phyto-chemical compositions of $A$. calamus whole plant and its different parts viz., roots, rhizomes, leave and essential oil. ${ }^{7-9}$ The major compounds identified from this plant are asarones ( $\alpha$ - and $\beta$ ), caryophyllene, isoasarone, methyl isoeugenol and safrol. ${ }^{7,8}$ Essential oil isolated from A. calamus rhizomes is also dominated by the presence of $\alpha$ - and $\beta$-asarone. ${ }^{9,10}$ Previously, we have reported antimicrobial and antioxidant properties of $A$. calamus leaves and rhizome., ${ }^{4,5}$ Although several previous studies have reported phytochemical compositions and bioactivities of $A$. calamus, reports on biochemical composition are not available. In view of increasing medicinal significance of $A$. calamus the present study was undertaken to analyze bio- chemical composition of the leaf and rhizhome tissues. The study indicated tissue specific variation in the biochemical compositions of the leaf and rhizome tissues.

\section{Materials and Methods}

\section{Plant material}

Acorus calamus (L.) plants were collected from the Horticultural Research Station, Yercaud in Tamil Nadu, India and grown in the Herbal Garden of Vellore Institute of Technology University, Vellore, Tamil Nadu, India. Fresh rhizomes and leaves were used for the extraction of carbohydrates and lipids.

\section{Extraction and estimation of lipids}

Total lipids were extracted according to the Folch's method. ${ }^{11}$ Leaves and rhizomes were weighed (10 g), made in to small pieces and mixed with $30 \mathrm{ml}$ of chloroform: methanol (2:1 $\mathrm{v} / \mathrm{v}$ ) and kept overnight at room temperature for extraction of the lipids. The contents were filtered, and residue was homogenized in pestle and mortar with chloroform and methanol $(2: 1 ; \mathrm{v} / \mathrm{v})$ and filtered again. The residue on the filter was given 2-3 washings with chloroform: methanol. All the filtrates were pooled in a separate conical flask to give final volume $50 \mathrm{~mL}$. This constituted the crude lipid extract. Methanol was added to make the ratio 1:1.The crude lipid extract was transferred into a separating funnel and $1 \% \mathrm{NaCl}$ solution was added to one forth of its volume. The contents was thoroughly mixed and allowed for phase separation by standing for few hours. The lower chloroform layer containing lipids were separated and upper methanol layer was washed twice with 5-10 mL of chloroform. The chloroform washings were pooled with earlier lipid extract in chloroform and resulting solution was evaporated at $40^{\circ} \mathrm{C}$. The process removes water. The lipid residue was made up to $10 \mathrm{~mL}$ with chloroform and stored at $-10^{\circ} \mathrm{C}$.

Glycolipids were estimated in the crude lipid extract as previously published procedures. ${ }^{12,13}$ Sterols and free fatty acids in the lipid extracts were estimated as per standard operating protocol.

\section{Extraction and estimation of carbo- hydrates}

Acorus calamus fresh leaves and rhizomes $(10 \mathrm{~g})$ were separately grounded with hot $80 \%$ ethanol using pestle and mortar. Sugars from leaves and rhizome materials were extracted with hot $80 \%$ ethanol for 2 times and 70\% ethanol for 4 times, stirred every time on magnetic stirrer-cum hot plate and centrifuged at $3250 \mathrm{rpm}$ for $15 \mathrm{~min}$. Ethanol extracts of leaves and rhizomes thus obtained were pooled sepa-
Correspondence: Deepak Ganjewala, Plant Biotechnology Center, Amity Institute of Biotechnology, Amity University, Sector-125, Noida-201303 (UP), India.

Tel. 91.120.4392946 - Fax: 91.120.4392295.

E-mail: deepakganjawala73@yahoo.com

Key words: acorus calamus, glycolipid, rhizome, sugar

Received for publication: 14 January 2011.

Revision received: 8 April 2011.

Accepted for publication: 16 May 2011.

This work is licensed under a Creative Commons Attribution 3.0 License (by-nc 3.0).

(C) Copyright D. Ganjewala et al., 2011

Licensee PAGEPress, Italy

International Journal of Plant Biology 2011; 2:e4 doi:10.4081/pb.2011.e4

rately in two beakers. The ethanol extracts were concentrated to aqueous syrup by evaporating at $40^{\circ} \mathrm{C}$. The last trace of ethanol was removed by raising temperature to $50^{\circ} \mathrm{C}$. The concentrated sugar syrup was transferred to $100 \mathrm{~mL}$ flask and volume raised to $98 \mathrm{ml}$ with distilled water. $1 \mathrm{ml}$ of saturated solution of basic lead acetate was added to remove proteins and volume made up to $100 \mathrm{ml}$. The contents were filtered and excess lead ions from filtrate were precipitated with sodium oxalate crystals and filtered again. Free sugars were estimated using this clear solution. The sugar free residue was used to estimate starch content. Starch was estimated using the Clegg method. ${ }^{14}$ The total sugars and reducing sugars in the extract were estimated respectively by the method of Yemm and Willis ${ }^{15}$ and Nelson. ${ }^{16}$ Total non-reducing sugar was calculated as the difference in the concentration of total sugars and total reducing sugars. Sucrose and fructose were determined afterwards in the same extract by the method of Handel. ${ }^{17}$ Sucrosyl fructose was determined by dividing the concentration of sucrose by 1.9 and the non-sucrosyl fructose from the difference in values of total and sucrosyl fructose.

\section{Results and Discussion}

Biochemical compositions, a of A. calamus leaf and rhizome tissues are presented in Table 1. To observe the tissue specific variation in biochemical composition amount of lipids: glycolipids, sterols and free fatty acids and carbohydrates: total sugars, reducing sugars, sucrose and fructose were measured in the leaf and rhizome tissues. The result showed significant variation in the levels of 
Table 1. Biochemical compositions of Acorus calamus leaf and rhizome tissues.

$\begin{array}{lcccc}\begin{array}{l}\text { Biochemical } \\ \text { parameters }\end{array} & \begin{array}{c}\text { Leaves } \\ \text { extract }\end{array} & \begin{array}{c}\mathrm{mg} \% \\ \text { fresh weight }\end{array} & \begin{array}{c}\text { Rg/g } \\ \text { extract }\end{array} & \begin{array}{c}\text { Rhizomes } \% \\ \text { fresh we }\end{array} \\ \text { Lipids } & & 28.8( \pm 0.57) & 99.7 & 62.3( \pm 1.15) \\ \quad \text { Glyco-lipids } & 46.2 & 47.9( \pm 15.3) & 25.0 & 15.6( \pm 10.0) \\ \quad \text { Sterols } & 76.7 & 3.7( \pm 0.5) & 3.3 & 2.1( \pm 1.08) \\ \quad \text { Free fatty acids } & 5.9 & 18.2( \pm 2.88) & & \\ \text { Carbohydrates } & & 6.1( \pm 0.57) & 14.1( \pm 8.6) \\ \quad \text { Total sugar } & 29.2 & 6.6( \pm 1.73) & 8.5 & 6.5( \pm 0.57) \\ \text { Total reducing sugar } & 9.8 & 4.4( \pm 1.73) & 10.5 & 5.3( \pm 0.0) \\ \text { Sucrose } & 10.5 & & & 6.6( \pm 1.73) \\ \quad \text { Fructose } & 7.0 & & \end{array}$

lipids in leaf and rhizome tissues. However, carbohydrate content measured in the leaf and rhizome tissues were more or less similar. In the rhizome tissue, the amount of glycolipid was 62.3 while in the leaf tissues only 28.8 $\mathrm{mg} \%$ fresh weight. In contrast to glycolipids, the amount of sterols in the leaf tissue was substantially high ( $48 \mathrm{mg} \%$ fresh weight) almost three times the sterol content $(16 \mathrm{mg} \%$ fresh weight) in the rhizome tissue. Free fatty acids content measured in the leaf tissue was slightly higher than rhizome tissues. As such no differences were seen in various sugar content in the leaf and rhizome tissues. However, total sugar content in the leaf tissue was found to be slightly higher (18 $\mathrm{mg} \%$ fresh weight) than in the rhizome tissue (14 $\mathrm{mg} \%$ fresh weight).

So far not any report has been published on biochemical composition of $A$. calamus leaf and rhizome tissue. However, many previously published reports describe the phytochemical composition and important bioactivities of the A. calamus whole plant, different parts such as leaves and rhizomes and essential oil, and major constituent asarones. ${ }^{1-10}$ Our study in $A$. calamus has revealed marked variation in asarone content of the leaf and rhizome. Asarone content also influenced by the environmental and seasonal factors (unpublished). The biochemical as well as the chemical compositions of the concerned plants parts or tissues is often influenced by different origins, environmental, seasonal and genetic factors. ${ }^{18-}$ ${ }^{21}$ Our previous study with four different types of Lantana camara bearing red, yellow, white and lavender flowers has revealed variation in the biochemical compositions of leaf and flower tissue. ${ }^{21}$ The levels of carbohydrates (mg/g dry weight) in the flowers were comparatively higher than in the leaves and the lipids content was relatively higher in the leaves except $L$. camara lavender and white. In lavender L. camara the amount of the total carbohy- drates was very low. Proteins electrophoretogram of leaf proteins revealed similarity among $L$. camara yellow, red, and white flowers while that of flowers proteins showed similarity between $L$. camara yellow, lavender, red, and white. ${ }^{21}$ In the present study differences observed in the biochemical compositions of $A$. calamus leaf and rhizome tissues are consistent with several previously published reports. These differences in the biochemical compositions could be due to different origin, developmental pattern and nature of the leaf and rhizome tissues.

\section{References}

1. Mehrotra S, Mishra KP, Maurya R, et al. Anticellular and immunosuppressive properties of ethanolic extract of Acorus calamus rhizome. Int Immunopharmacol 2003;3:53-61.

2. Manikandan S, Devi RS. Antioxidant property of $\alpha$-asarone against noise-stressinduced changes in different regions of rat brain. Pharmacol Res 2005;52:467-74.

3. Phongpaichit S, Pujenjob N, Rukachaisirikul V, Ongsakul M. Antimicrobial activities of the crude methanol extract of Acorus calamus Linn. Malaysian J Sci Technol 2005;27:517-23.

4. Asha Devi S, Ganjewala D. Antimicrobial properties of Acorus calamus (L.) rhizome and leaves extract. Acta Biol Szeg 2009;53:45-9.

5. Asha Devi S, Ganjewala D. Antioxidant activities of methanolic extracts of Acorus calamus (L.) rhizome and leaves. J Herbs Spices Med Plants 2011;17:1-11.

6. Kim H, Han TH, Lee SG. Anti-inflammatory activity of a water extract of Acorus calamus L. leaves on keratinocyte HaCaT cells. J Ethnopharmacol 2009;122:149-56.
7. Namba T. The encyclopedia of WakanYuku (tradional Sino Japanese medicines, with color picture). Hoikusha, Osaka: Japan; 1993;1:606.

8. Wang HZ, Cheng YG, Fan GS. Review of studies on chemical constituents and pharmacology of genus Acorus. Acta Bot Yunn 1998;20:96-100.

9. Raina VK, Srivastava SK, Syamasunder KV. Essential oil composition of Acorus calamus L. from the lower region of the Himalayas. Flavor Fragrance J 2003;18:1820.

10. Oprean R, Tamas M, Roman L. Comparison of GC-MS and TLC techniques for asarone isomers determination. J Pharm Biomed Anal 1998;18:227-34.

11. Folch J, Lees M, Sloane-Stanley GH. A simple method for the isolation and purification of total lipides from animal tissues. J Biol Chem 1957 226:497-9.

12. Roughan PC, Batt RD. The glycerolipid composition of leaves. Phytochemistry 1969;8:363-9.

13. Lowry RR, Tinsley IJ. Rapid calorimetric determination of free fatty acids. J Am Oil Chem Soc 1976;53: 470-2.

14. Clegg KM. The application of anthrone reagent to the estimation of starch in cereals. J Sci Food Agric 1965;7:40-4.

15. Yemm EW, Willis AJ.The estimation of carbohydrates in plant extracts by anthrone. Biochem J 1954;57:508-14.

16. Nelson N. A photometric adaptation of the Somogyi method for the determination of glucose. Biol Chem 1944;153:375-80.

17. Handel E. Direct micro determination of sucrose. Anal Biochem 1968;22:280-3.

18. Randrianalijaona JA, Ramanoelina PAR, Rasoarahona JRE, et al. Seasonal and chemotype influences on the chemical composition of Lantana camara L.: Essential oils from Madagascar. Anal Chimica Acta 2005;545:46-52.

19. Bhakta D, Ganjewala D. Effect of leaf positions on total phenolics, flavonoids and proanthocyanidins content and antioxidant activities in Lantana camara (L). J Sci Res 2009;1:363-9.

20. Priya K, Ganjewala D. Antibacterial Activities and Phytochemical Analysis of Different Plant Parts of Nyctanthes arbortristis L. Res J Phytochem 2007;1:61-7.

21. Ganjewala D, Sam S, Khan KH. Biochemical compositions and antibacterial activities of lantana camara (1.) plants bearing yellow, lavender, red and white colour flowers. EurAsian J Biosci 2009;3: 69-77. 